\title{
ISOLATION OF A LIPASE-PRODUCING TRICHOSPORON SPP AND ENZYME EXTRACTION BY TWO-PHASE AQUEOUS SYSTEM
}

\author{
Juliana A. Santos ${ }^{1,2}$; Marcel C.O. Amaral ${ }^{2}$; Thiago A.S. Araújo ${ }^{1,3}$; Késsia G.C. Fernandes ${ }^{1,3}$; Adilson C. Chaves ${ }^{1,3}$; \\ Márcia M. C. Morais ${ }^{1 *}$ \\ ${ }^{1}$ Institute of Biological Sciences, University of Pernambuco, Recife, Pernambuco, Brazil; ${ }^{2}$ Laboratory of Imunopathology Keizo \\ Asami (LIKA) and Department of Genetics - Federal University of Pernambuco - Recife, Pernambuco, Brazil; ${ }^{3}$ Department of \\ Exact and Natural Sciences, University of Pernambuco, Nazaré da Mata, Pernambuco, Brazil
}

Submitted: February 13, 2006; Returned to authors for corrections: March 30, 2006; Approved: October 13, 2006

\section{SHORT COMMUNICATION}

\begin{abstract}
A lipase-producing yeast strain isolated from crude cheese and identified as Trichosporon spp produced 7.3 $\mathrm{U} / \mathrm{mL}(59.3 \mathrm{U} / \mu \mathrm{g})$ after $72 \mathrm{~h}$ of cultivation. Lipase showed optimum activity at $\mathrm{pH} 7.0-8.0$ and $45-50^{\circ} \mathrm{C}$. Extraction by the two-phase aqueous system (PEG-phosphate salts) showed an elevated recuperation $(99.8 \%$ ) of enzymatic activity in the PEG phase.
\end{abstract}

Key words: extracellular lipase, Trichosporon, aqueous two phase system, PEG

Lipolytic enzymes are frequently used for conferring different flavours of cheeses during cheese production. Most of these enzymes are produced by the milk yeast microbiota (4). Search for good lipase sources is often accompanied by the necessity of alternative ways for enzyme extraction, which can be related to a simple culture-medium design (3) or to the application of selective methods of enzyme separation. The aqueous two phase system (ATPS) is used for separation and purification of biomaterials and it is produced when aqueous solutions of polymers and salts or two polymers are mixed. The most used system is constituted by poly(ethylene) glycol (PEG) and phosphate salts (9). In this work, we report the isolation of lipase-producing yeast identified as Trichosporon spp and enzyme extraction by the ATPS PEG-phosphate salts. Thirty yeast isolates from crude cheese were screened for lipase production in Victoria Blue solid medium according to Samad (10). A secondary selection was performed by inoculating a liquid basal medium containing yeast extract (10 g/L), $\mathrm{MgSO}_{4}$ $(0.1 \mathrm{~g} / \mathrm{L}), \mathrm{KH}_{2} \mathrm{PO}_{4}(1.0 \mathrm{~g} / \mathrm{L})$ and $1.0 \%(\mathrm{v} / \mathrm{v})$ triolein with $10^{8}$ cells/ $\mathrm{mL}$. Lipase activity was determined by the pNPP method (8). One unit $(\mathrm{U})$ of enzymatic activity was defined as the release of
$1 \mu \mathrm{mol}$ of p-nitrophenol per min. Protein determinations were performed according to Bradford (1). Aqueous two phase system was prepared as described by Queiroz et al (9). The isolated Trichosporon spp produced up to $7.3 \mathrm{U} / \mathrm{mL}$ after $72 \mathrm{~h}$ of cultivation. Optimum $\mathrm{pH}$ and temperature were $\mathrm{pH}$ 7.0-8.0 and $45-50^{\circ} \mathrm{C}$, respectively, similarly to other microbial lipases. Yeasts of the genus Trichosporon have been frequently isolated from milk and dairy products (4) and many Trichosporon species have been used for lipase production and isolation $(5,7)$. Lipase extraction was tested in different $\mathrm{pH}$ values and tie line lengths. The enzyme preferably partitioned to the PEG phase, probably due to the hydrophobic properties of PEG, as also observed by other authors (2). Particularly, best results were shown with PEG 8000, tie line 2.0 at $\mathrm{pH} 8.0$, with coefficient of partition 2.69 (Figure 1). In this system, $99.8 \%$ of the lipase activity present in the system was recovered in the PEG phase. Moreover, specific activity was the highest observed (Table 1), with the purified enzyme maintaining its optimal $\mathrm{pH}$ and temperature of activity. Nevertheless, the purification factor and yield values achieved suggested that the system must be optimized to reach better yields. Thus, the results indicate that the combination presented

*Corresponding Author. Mailing address: UPE - Dep. de Patologia - ICB - Rua Arnóbio Marques, 310 Santo Amaro. Cep 50100-130 Recife, PE - Brasil. Tel.: (81) 3421-1769 ou (81) 3423-8582. E-mail: camargo@ icb.upe.br 


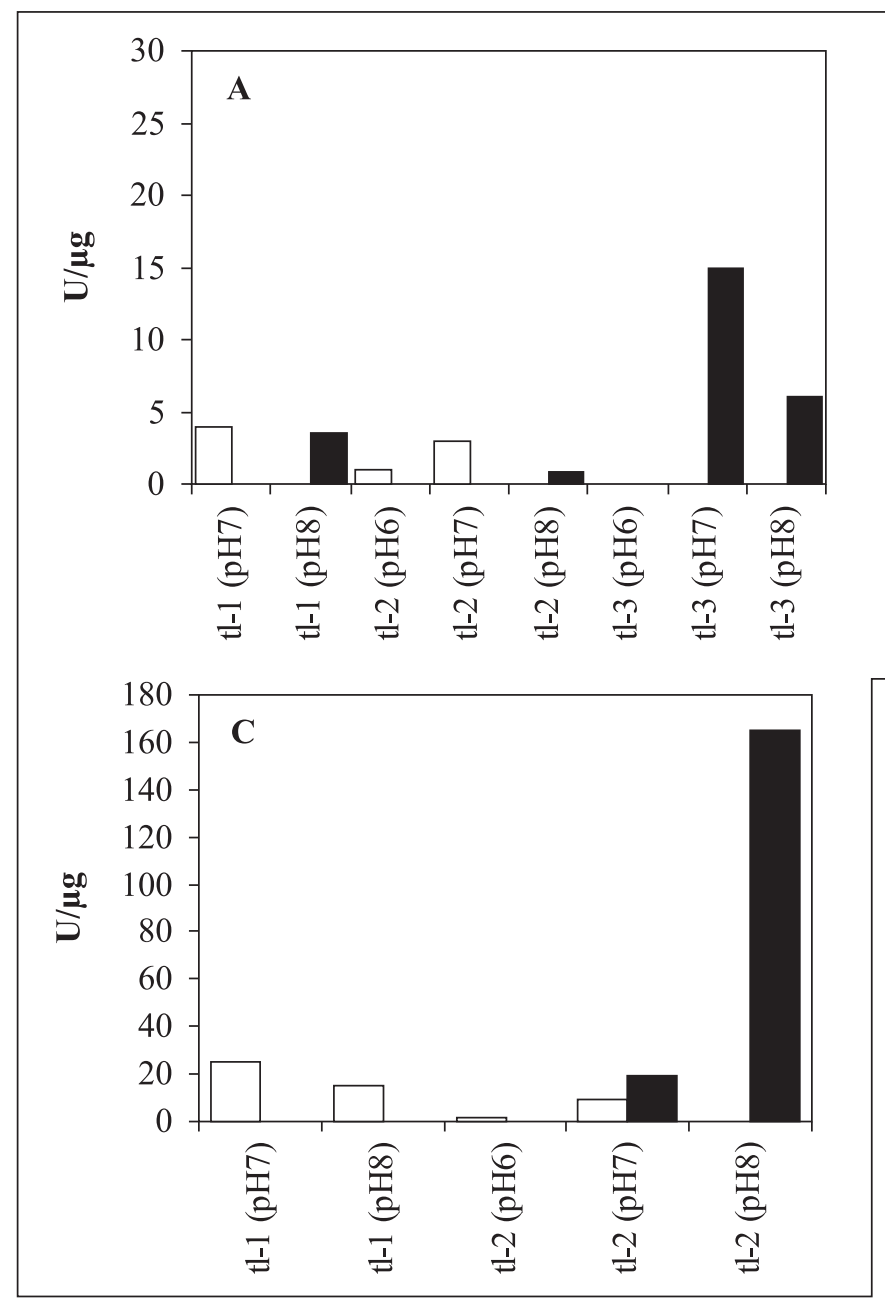

Figure 1. Specific lipase activity in systems containing PEG 1000 (A), PEG 3350 (B) and PEG 8000 (C) in different tie-lines and $\mathrm{pH}$ values. tl: tie line.

Table 1. Extraction of Trichosporon spp lipase with two-phase aqueous system using PEG-8000, tie line 2 and $\mathrm{pH}$ 8.0.

\begin{tabular}{lcccccc}
\hline & $\begin{array}{c}\text { Lipase } \\
\text { activity } \\
(\mathrm{U} / \mathrm{mL})\end{array}$ & $\begin{array}{c}\text { Protein } \\
(\mu \mathrm{g} / \mathrm{mL})\end{array}$ & $\begin{array}{c}\text { Specific } \\
\text { activity }\end{array}$ & $\begin{array}{c}\text { Purification } \\
\text { factor } \\
(\mathrm{U} / \mu \mathrm{g})\end{array}$ & $\begin{array}{c}\text { Yield } \\
(\%)\end{array}$ & $\begin{array}{c}\text { Coefficient } \\
\text { of partition }\end{array}$ \\
\hline Crude extract & 7.3 & 0.123 & 59.3 & 1 & 100 & 1 \\
PEG8000 & 1.5 & 0.009 & 166.6 & 2.80 & 20.5 & 2.69 \\
\hline
\end{tabular}

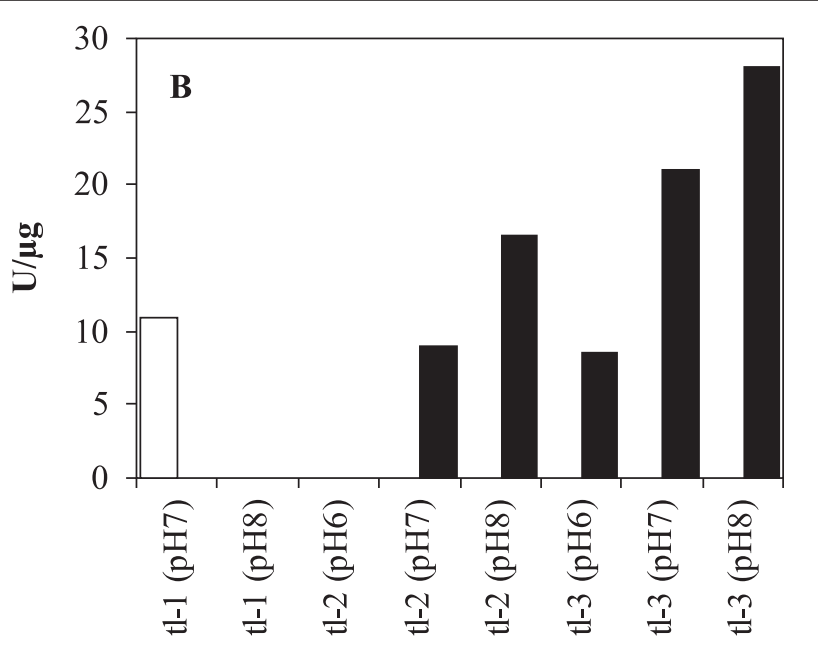

\section{RESUMO}

\section{Isolamento de Trichosporon spp produtor de lipase e extração enzimática pelo sistema bifásico aquoso}

Uma levedura produtora de lipase isolada de queijo coalho e identificada como Trichosporon spp produziu 7,3 U/mL (59,3 $\mathrm{U} / \mu \mathrm{g}$ ) após $72 \mathrm{~h}$ de cultivo. A lipase mostrou atividade ótima em pH 7,0-8,0 e temperatura ótima entre $45-50^{\circ} \mathrm{C}$. Extração pelo sistema PEG - sais de fosfato apresentou $99,8 \%$ de recuperação da atividade enzimática na fase PEG.

Palavras-chave: lipase extracelular, Trichosporon, sistema bifásico aquoso

\section{REFERENCES}

1. Bradford, M.M. (1976). A rapid and sensitive for the quantification of microgram quantities of protein utilizing the principle of protein-dye binding. Anal. Biochem., 72, 248-254.

2. Bradoo, S.; Saxena, R.K.; Gupta, R. (1999). Partitioning and resolution of mixture of two lipases from Bacillus stearothermophilus SB1 in aqueous two-phase system. Process Biochem., 35, 57-62.

3. Camargo de Morais, M.M.; Maia, M.M.D.; Borba, F.F.S.; Melo, K.G.; Santos, C.M.S.O.; Reis, E.R.A.; Morais Jr, M.A.; Lima Filho, J.L. (2003). Oil/ mineral-salts médium designed for easy recovery of extracellular lipase from Fusarium oxysporum AM3. World J. Microb. Biot., 19, 17-20.

4. Corbo, M.R.; Lanciotti, R.; Albenzio, M.; Sinigaglia M. (2001). Ocurrence and characterization of yeasts isolated from milks and dairy products of Apulia region. Int. J. Food Microbiol., 69, 147-152.

here of the Trichosporon spp isolate and the PEG/phosphatesalts system has a good potential for high lipase production and rapid enzymatic recovering.
5. Dharmsthiti, S.; Ammaranond, P. (1997). Purification and characterization of lípase from raw-milk yeast (Trichosporon asteroides). Biotechnol. Appl. Biochem., 26, 111-116. 
Morais, M.M.C. et al.

6. Fernandez-Lorente, G.; Ortiz, C.; Segura, R.L.; Fernandez-Lafuente, R.; Guisan, J.M.; Palomo, J.M. (2005). Purification of different lipases from Arpergillus niger by using a highly selective adsorption on hydrophobic supports. Biotechnol. Bioeng., 92, 773-779.

7. Phan, T.M.D.; Villa, E.M.D.; Wichmann, R. (2005). Development of an integrated process for the production and isolation of a lipase from Trichosporon beigilie. J. Biotechnol, 118, S57-S57 Suppl. 1.

8. Pimentel, M.C.B.; Krieger, N.; Coelho, L.C.C.B.; Fontana, J.O.; Melo, E.H.M.; Ledingham, W.M.; Lima-Filho, J.L. (1994). Lipase

from a Brazilian strain of Penicilium citrinum. Appl. Biochem. Biotech., 49, 59-74.

9. Queiroz, J.A.; Garcia, F.A.P.; Cabral, J.M.S. (1995). Partitioning of Chromobacterium viscosum lipases in aqueous two-phase systems. Biosep., 5, 307-311.

10. Samad, M.Y.A.; Razak, C.N.A.; Salleh, A.B.; Yunus, W.M.Z.W.; Ampon, K.; Basri, M. (1989). A plate assay for primary screening of lípase activity. J. Microbiol. Meth., 9, 51-56. 